\title{
Perceptions of Vegan Food among Organic Food Consumers Following Different Diets
}

\author{
David Kilian *(1) and Ulrich Hamm \\ Department of Agricultural and Food Marketing, University of Kassel, Steinstrasse 19, \\ 37213 Witzenhausen, Germany; hamm@uni-kassel.de \\ * Correspondence: d.kilian@uni-kassel.de
}

Citation: Kilian, D.; Hamm, U. Perceptions of Vegan Food among Organic Food Consumers Following Different Diets. Sustainability 2021, 13, 9794. https://doi.org/10.3390/ su13179794

Academic Editor: Pekka Jokinen

Received: 27 July 2021

Accepted: 27 August 2021

Published: 31 August 2021

Publisher's Note: MDPI stays neutral with regard to jurisdictional claims in published maps and institutional affiliations.

Copyright: (c) 2021 by the authors. Licensee MDPI, Basel, Switzerland. This article is an open access article distributed under the terms and conditions of the Creative Commons Attribution (CC BY) license (https:// creativecommons.org/licenses/by/ $4.0 /)$.

\begin{abstract}
This article identifies consumer segments for vegan food by analysing perceptions of vegan food among food organic consumers following different diets: vegans, vegetarians, former vegetarians, flexitarians, and omnivores. The analysis is based on responses to a quantitative consumer survey for which 503 participants were recruited from customers at German grocery stores by quota sampling according to diet and region. From the responses to an open-ended question eliciting the participants' associations with vegan food, the analysis finds that vegans and vegetarians perceive vegan foods primarily as being beneficial for animal welfare, healthy, and environmentally friendly, while those who ate meat perceive vegan food primarily as containing no animal ingredients and as being healthy. The respondents' varying assessments of the taste, diversity, and environmental benefits of vegan food were found to differ in relation to the various diets they followed, as did their assessments of how long the vegan trend is likely to last. A cluster analysis based on the consumers' perceptions and attitudes revealed three consumer groups: "vegan fans", "enjoyment sceptics", and "originality-sceptics". Scepticism about the originality of vegan food was found in all diet groups. These findings can help inform more effective targeting of consumer needs for vegan organic food.
\end{abstract}

Keywords: vegan; vegetarian; plant-based; consumer segments; organic food; consumer attitudes; motives

\section{Introduction}

A vegan diet is particularly sustainable and is considered as an effective way to reduce diet-related greenhouse gas emissions [1-6]. The most environmentally friendly diet is the vegan diet based on organic food [7] and multiple studies have shown that consumers who have a strong preference for organic food tend to consume less meat or animal products than other consumers [8-13] and more vegetables and fruits [14]. Thus, organic food consumers are an interesting target group to increase the consumption of vegan food and to promote a shift towards more sustainable diets. It is therefore worthwhile to analyse how organic food consumers perceive vegan food in order to be able to address these consumers as a target group for vegan food and consequently increase the sales of vegan food. Moreover, the size of the group of organic food consumers is quite large-in Germany, organic food is currently bought at least occasionally by $80 \%$ of consumers [15] (p. 9).

The overall objective of the study was to explore the perception of organic food consumers towards vegan food. The aim is to analyse consumers' associations and attitudes towards vegan food by defining different consumer group profiles. Given the very different diet styles followed by contemporary consumers [16-21] a special focus is set on a differentiation of consumers according to their diet preferences. Furthermore, the explorative segmentation process is based on the perceptions and attitudes of consumers regarding vegan food. The findings of the study can be used to improve the development of vegan products and better tailor them to consumer needs as well as for improving communication measures about vegan food products. 
The paper is organized as follows: Section 2 reviews the literature both on consumers' motives for following vegan, vegetarian, and meat-reduced diets and on the perceptions and attitudes of consumers regarding vegan food; Section 3 introduces the methods of data collection and analysis; Section 4 presents the results of the empirical investigation; and Section 5 discusses the main results, identifies some limitations of the study, and draws conclusions for marketers of vegan food.

\section{Literature Review}

\subsection{Consumer Attitudes to Vegan Food}

Previous studies have focused on consumer attitudes to vegan foods in general as well as more particularly on attitudes to meat substitutes and foods with plant protein. According to a literature review by He et al. [22], the basic acceptance of plant-based meat alternatives has increased slightly in recent years but still remains low. Taste has been identified in several review articles as a critical factor for the acceptance of vegan meat alternatives and a plant-based diet [23-25].

Consumers who attach more importance to health and naturalness when shopping for groceries also tend to eat plant-based dishes more often [26]. Abstaining from meat and consuming meat substitutes are both generally considered to be healthy practices. However, meat substitutes are also perceived as unhealthy by some consumers due in part to the assumption that meat avoidance leads to malnutrition $[27,28]$. Soya milk has also been found to be considered unnatural and unhealthy than cow milk [29]. A study by Miguel et al. [30] has confirmed that ethical motives, specifically attitudes towards environmental protection and animal welfare, have a significant effect on attitudes towards vegan food and consequently influence consumers' involvement with vegan food, their purchase intentions for vegan food and the likelihood of their recommending vegan food to other consumers by word of mouth. Overall, a plant-based diet is perceived as environmentally friendly and environmental concern increases consumers' purchase intention for plant-based meat substitutes and vegan products [31-34]. Weinrich [24] concludes that the health and environmental benefits of meat substitutes are important for attracting the attention of consumers to these products, although whether such substitutes will be consumed more frequently depends primarily on how they taste. Consumers perceive vegan food and meat substitutes as expensive and studies have identified expensiveness as a major barrier to the purchase of plant-based products $[27,35-38]$.

\subsection{Diet Styles and Motivations to Abstain from Animal-Based Food}

With regard to the consumption of animal-based food, a distinction can be made between different diets: According to the International Vegetarian Union, vegetarians follow "a diet of foods derived from plants, with or without [emphasis in original] dairy products, eggs and/or honey" whereas vegans "exclude "any use of any animal products for any purpose" [39]. "A person who follows a primarily but not strictly vegetarian diet" is called flexitarian [40]. Despite the increasing prevalence of flexitarian diets, there is no generally accepted definition of the degree of meat reduction required to be classified as a flexitarian, and the definitions of flexitarianism used in scientific studies vary in detail [41].

People's motivations for abstaining from meat and following a vegetarian diet have been investigated in numerous studies. Reviews of these studies by Ruby [42] and Rosenfeld [43] have shown that concerns about animal welfare, health benefits, and environmental protection are consistently found to be key motivations for a vegetarian diet. The majority of these studies have identified animal welfare as the primary motive for a large proportion of vegetarians and vegans, while a smaller number of studies have found health to be the most prevalent motivation.

Regarding the main motives, no differences can be found between a vegetarian diet in general and a stricter vegan diet. Studies that have explicitly examined motives for adopting a vegan diet have identified three major motivations for choosing a vegan diet: firstly, ethical concerns, especially concerns about animal welfare [44-52]; secondly, health 
reasons [46-53]; and thirdly, somewhat less important, concerns about the environment and climate change $[44-47,51,53,54]$.

Some of the reviewed studies identified other motives for adopting a vegan diet, including taste-related factors $[48,52]$ religious beliefs and practices $[44,53]$, global/humani- tarian reasons [48], and the influence of individuals' social and family environments $[44,48,53]$.

People's decision to follow a vegetarian diet is not necessarily a permanent decision. Many people resume meat consumption after a period of vegetarianism, often for health reasons such as concerns about malnutrition $[16,55,56]$. Factors in one's personal social environment have also been found to have an important influence on people's decision to return to eating meat $[16,56,57]$.

The reasons for reducing the consumption of meat, i.e., for following a "flexitarian" diet, are found to be similar to the reasons for abstaining from meat altogether. However, ethics related to animals are less important for flexitarians than for vegetarians $[17,58,59]$. A study by Izmirli and Phillips [60] has identified concerns for environmental protection as the most important motive for adopting a flexitarian diet, although several other studies have found that environmental protection is generally considered less important by flexitarians than vegetarians $[17,20,51,61-63]$. Health reasons are often identified as a particularly important motive for adopting a flexitarian diet $[17,18,20,51,63,64]$.

On the basis of these reviewed findings on the factors involved in people's renunciation of animal products, the following five diet-related consumer groups seem to be of particular importance for the study of vegan food consumption: vegans, vegetarians, former vegetarians, flexitarians, and omnivores. Vegans and vegetarians together are estimated to comprise between $3 \%$ and $10 \%$ of the German population [65], [66] (p. 81), [67] (p. 81), [68], with vegans constituting $0.3 \%$ to $1.6 \%$ of the total population [65] (p. 12), [66] (p. 81), [67] (p. 81), [68] (p 252). Data on the prevalence of flexitarian diets in Germany vary greatly due to the lack of a generally accepted definition of the term "flexitarian", with estimates ranging from $12 \%$ to as much as $55 \%$ of the population [65] (p. 12), [69] (p. 59). In the current paper, flexitarians are defined as persons who either consciously abstain from meat at times or eat meat only rarely, while "former vegetarians" refers to those respondents who had followed a vegetarian diet for at least half a year in the past before resuming meat-eating, regardless of whether they now ate meat frequently or selectively. There are no current figures on the prevalence of former vegetarians in the population of Germany.

\section{Materials and Methods}

\subsection{Data Collection}

The target group of this study were consumers in Germany who buy organic food. Accordingly, only those consumers who answered "yes" to the screening question "Do you buy organic food several times a year?" were invited to participate in the interview. Further screening questions clarified which of the five diets each person followed, i.e., vegan, vegetarian, former vegetarian, flexitarian, or omnivore. For each of these different diets, the number of participants selected was determined by predefined quotas. As vegans are a particularly important but relatively small and also rarely researched target group for vegan food, a non-proportional quota sampling strategy was used. More vegans were interviewed to compensate the uncertainties resulting from the lack of knowledge about this rare dietary habit. Specifically, it was planned to interview 150 vegans and 75 people from each of the groups following non-vegan diets. To ensure an adequate geographical distribution of interviews, quotas were also specified for the number of participants from the north, south and east of Germany.

For recruiting the survey participants, face-to-face interviews were conducted in organic food shops, vegan food shops, and general food shops. To minimize socialdesirability bias, the interviews for the study were carried out by the participants on laptops in the shops in the form of a computer-assisted self-administered survey. A total of 503 customers were surveyed, of whom 152 were vegans. 
A market research institute was contracted to select the shops, recruit the participants, and conduct the self-administered surveys in the shops. To ensure high data quality and prevent interviewer fraud, the interviewers were checked by university staff.

The questionnaire contained questions about sociodemographic characteristic (age, gender), meat consumption frequency (translated question wording: "How often do you usually eat meat and/or sausages"; answer options: (a) daily, (b) four to six days per week, (c) on one to three days per week, (d) less than once a week, but several times a month, (e) at most once a month, but several times a year, (f) once a year or less; question was only presented to meat-eating respondents), the duration of the current diet (translated question wording: "For how many years have you been following a vegan diet?" for vegans and "For how many years have you been following a vegetarian diet?" for vegetarians) and questions about respondents' attitudes to vegan food. The participants were first asked to respond to an open-ended question in order to elicit their associations with vegan food (translated question wording: "What do you associate with vegan food? Please name up to three characteristics or terms that come to your mind spontaneously"). A seven-point semantic differential scale with eight bipolar pairs was then used to underpin the answers given to the initial open-ended question. The participants were further asked to indicate their responses to a series of statements on a seven-point Likert scale (translated question wording: "Please indicate which characteristics apply to processed vegan food in your view. Answer spontaneously and don't take too much time to think about". These statements were randomised to prevent any order effect. To clarify the use of the term "vegan food" in the survey, it was pointed out to participants that this term referred here to processed food and not to fruit and vegetables. The final questionnaire was pretested with individuals of a convenience sample.

\subsection{Data Analysis}

All Analysis of the responses to the open-ended question about associations with vegan food was undertaken in three steps. Two researchers first individually and separately developed categories for the survey responses, inductively deriving a system of categories from the answers given. These categories were then synthesized to produce a unified category system of 19 categories. In a second step, two researchers separately categorised all answers according to the developed category system. The researchers' categorisations were found to be mutually consistent for $90 \%$ of the categorised terms. In a third step, all terms that were not classified in the same category were discussed by the researchers to select the most suitable categories for each term. This consensual coding safeguarded the reliability of the coding process and ensured all terms were assigned to an appropriate category [70] (p. 74).

The analysis was differentiated according to the five consumer groups following different diets. A one-way analysis of variance (ANOVA) was used for interval-scaled variables to test differences among means. For multiple comparisons between the five groups, a post-hoc test with Bonferroni correction was used [71] (p. 447). Where the assumption of homogeneity of variances was violated (Levene-test, $p<0.05$ ), the Welch-test and a Games-Howell post hoc test were applied.

For further data analysis, a principal component analysis (PCA) based on the results of the semantic differential was conducted to reduce the number of variables for the cluster analysis. A sufficient correlation of variables is a prerequisite for performing PCA. This requirement was tested by Bartlett's test of sphericity and by examining the measure of sampling adequacy (MSA) values for each variable and the MSA values overall [72] (p. 104). To ensure that the variance of the variables was sufficiently represented by the factors, variables with communalities below 0.5 were deleted [72] (p. 119). To determine the number of factors, a parallel analysis was conducted according to Horn's [73] method. To facilitate factor interpretation, an orthogonal factor rotation was performed using the VARIMAX method [72] (p. 115). 
The next step in the data analysis was a cluster analysis based on the factors derived from the the PCA. To identify outliners, the agglomerative next neighbour hierarchical technique (single linkage method) was applied (based on Euclidean distance). Different clustering techniques were used to determine the appropriate number of clusters in order to balance the advantages and disadvantages of each method [74] (p. 77). A further hierarchical cluster analysis was conducted using Ward's clustering method (also based on Euclidean distance) and the partitioning clustering method "k-means" was applied. The k-means cluster analysis was calculated for different numbers of clusters in the range of two to seven and the results were compared with each other on the basis of the withinsum-of-squares values. The optimal number of clusters was determined using the elbow method [75] (pp. 42-44) and on the basis of the average silhouette width [76] (p. 129). In addition, the k-means analysis was run 2000 times with random starting points in order to avoid any bias arising from the predefined initial values.

\section{Results}

\subsection{Socio-Demographics}

The socio-demographic characteristics of the sample are summarised in Table 1 according to the different diets of the participants. Women comprised the majority of participants in all diet groups except for the omnivores group in which there were an equal number of female and male participants. Regarding the age of the respondents, the proportion of vegan consumers below 40 years old was particularly high $(60 \%)$, while only $5 \%$ of the vegan consumers were 60 years old and over, in contrast to the German population as a whole in which these shares are $27 \%$ and $28 \%$, respectively. The average age of vegans, 37.7 years, was consequently somewhat lower than the average age of persons following other diets (41.4 years to 47.9 years).

Table 1. Socio-demographic characteristics of the sample.

\begin{tabular}{|c|c|c|c|c|c|c|}
\hline & Vegans & Vegetarians & $\begin{array}{c}\text { Former } \\
\text { Vegetarians }\end{array}$ & Flexitarians & Omnivores & $\begin{array}{c}\text { German } \\
\text { Population }\end{array}$ \\
\hline $\mathrm{N}$ & 152 & 96 & 91 & 89 & 75 & \\
\hline $\begin{array}{c}\text { Gender: Proportion } \\
\text { of women }\end{array}$ & $64 \%$ & $78 \%$ & $71 \%{ }^{1}$ & $60 \%{ }^{2}$ & $50 \%{ }^{3}$ & $51 \% 4$ \\
\hline Age in years [Mean (SD)] & $37.7(12.2)$ & $41.4(14.1)$ & $47.9(13.2)$ & $43.4(15.6)$ & $43.5(14.9)$ & $44.3^{5}$ \\
\hline Aged 18 to under 40 years & $60 \%$ & $52 \%$ & $43 \%$ & $34 \%$ & $44 \%$ & $32 \%$ 5,6 \\
\hline Aged 40 to under 60 years & $36 \%$ & $34 \%$ & $42 \%$ & $38 \%$ & $41 \%$ & $35 \% 5,6$ \\
\hline Aged 60 years and over & $5 \%$ & $14 \%$ & $15 \%$ & $28 \%$ & $15 \%$ & $33 \% 5,6$ \\
\hline
\end{tabular}

$\mathrm{SD}=$ standard deviation; ${ }^{1-3}$ Due to missing values for the variable gender, the number of responses deviates: ${ }^{1} \mathrm{~N}=89 ;{ }^{2} \mathrm{~N}=87 ;{ }^{3} \mathrm{~N}=74$.

${ }^{4}$ Source: [77]. ${ }^{5}$ Source: [78] (pp. 11-12). ${ }^{6}$ German Population 18 years and older.

\subsection{Frequency of Meat Consumption}

At the beginning of the survey, the meat-eating participants were asked how often they consumed meat (Table 2). The most frequent consumers of meat were the omnivore group, only $1 \%$ of whom ate meat less than once a week and $23 \%$ ate meat every day. The second most frequent eaters of meat were the flexitarians, i.e., those participants who had stated in the screening interview that they consciously abstained from meat at times or 'only rarely' ate meat. Of the flexitarians, $22 \%$ of ate meat less than once a week, but several times a month, and a further $6 \%$ ate meat at most once a month, but several times a year. The former vegetarian participants consumed meat considerably less frequently than the flexitarians, with only $7 \%$ of this group consuming meat on four days per week or more. A Kruskal-Wallis test revealed that there was a significant difference in the frequency of meat consumption between vegetarians, flexitarians and omnivores (Kruskal-Wallis test $\mathrm{H}(2)=100,381, p<0.001)$. 
Table 2. Frequency of meat consumption.

\begin{tabular}{cccc}
\hline & Former Vegetarians & Flexitarians & Omnivores \\
\hline $\mathrm{N}$ & 91 & 89 & 75 \\
\hline Daily & $0 \%$ & $3 \%$ & $23 \%$ \\
Four to six days per week & $7 \%$ & $15 \%$ & $45 \%$ \\
On one to three days per week & $36 \%$ & $54 \%$ & $31 \%$ \\
Less than once a week, but & $30 \%$ & $22 \%$ & $1 \%$ \\
several times a month & $22 \%$ & $6 \%$ & $0 \%$ \\
At most once a month, but & $5 \%$ & $0 \%$ & $0 \%$ \\
several times a year & & & \\
Once a year or less & &
\end{tabular}

\subsection{Duration of Vegan and Vegetarian Diets}

The survey asked the vegan and vegetarian respondents to indicate how long they had been following their respective diets. Of the vegans, $12 \%$ had followed this diet for more than ten years, although $80 \%$ had followed a vegetarian diet prior to switching to a vegan diet. The average duration of following a vegan diet was 5.9 years, with the median duration being five years. If the period of their vegetarian diet prior to adopting a vegan diet is also taken into consideration, however, the proportion of vegans who had followed vegan or vegetarian diets for more than ten years was $47 \%$. On average, the vegans had followed a vegan or vegetarian diet for 12.6 years, with a median duration of nine years.

Quite similar results were found for vegetarians, who on average had been following their diet for 13.5 years, while the median duration of being vegetarian was ten years. Some $47 \%$ of the vegetarian respondents had abstained from meat for more than ten years.

\subsection{Associations with Vegan Food}

Table 3 presents the participants' responses to the open question about their associations with vegan food according to the five different diet groups. The fact that vegan food is free of any animal ingredients was reflected in many answers to this question. The responses of the vegan and vegetarian groups expressed this aspect more often through associations which are summarised in the category "aspects of animal husbandry". This category includes associations with animal welfare and animal husbandry, i.e., statements that vegan foods could render animal husbandry redundant and end animal suffering, with some responses citing specific aspects of animal husbandry to which they objected. Thus, $39 \%$ of the vegans (most frequent association of vegans) and $24 \%$ of vegetarians mentioned associations that fell into this category. By contrast, the groups of respondents who at least occasionally ate meat made fewer associations of vegan food with animal husbandry in their responses to this question ( $18 \%$ of flexitarians, $6 \%$ of former vegetarians, and $4 \%$ of omnivores), more often simply mentioning the fact that vegan food has no animal ingredients ( $31 \%$ of flexitarians, $35 \%$ of former vegetarians, and $37 \%$ of omnivores).

Terms like "healthy" and "health" were frequently associated with vegan food in the respondents' answers, including specific descriptions of such food as being "low-fat" and "rich in vitamins", etc. Health aspects were associated with vegan products not only by vegetarians ( $40 \%$ ) and vegans $(34 \%)$, moreover, but also by the meat-eating participants (associated by $26 \%$ of flexitarians, $23 \%$ of former vegetarians, and $25 \%$ of omnivores). On the other hand, some consumers perceived vegan food as "unhealthy" or "rich in fat", with some using terms like "malnutrition" in association with vegan products (mentioned by $6 \%$ of vegans, $4 \%$ of vegetarians, $7 \%$ of flexitarians, $12 \%$ of former vegetarians and $15 \%$ of omnivores). 
Table 3. Associations with vegan food.

\begin{tabular}{|c|c|c|c|c|c|c|c|c|c|}
\hline \multicolumn{2}{|l|}{ Vegans } & \multicolumn{2}{|l|}{ Vegetarians } & \multicolumn{2}{|c|}{ Former Vegetarians } & \multicolumn{2}{|l|}{ Flexitarians } & \multicolumn{2}{|l|}{ Omnivores } \\
\hline \multicolumn{2}{|l|}{$\mathbf{N}=150$} & \multicolumn{2}{|l|}{$N=96$} & \multicolumn{2}{|l|}{$N=89$} & \multicolumn{2}{|l|}{$N=84$} & \multicolumn{2}{|l|}{$N=71$} \\
\hline $\begin{array}{l}\text { aspects of } \\
\text { animal } \\
\text { husbandry }\end{array}$ & $39 \%$ & healthy & $40 \%$ & other & $33 \%$ & $\begin{array}{l}\text { without animal } \\
\text { ingredients }\end{array}$ & $35 \%$ & $\begin{array}{l}\text { without animal } \\
\text { ingredients }\end{array}$ & $37 \%$ \\
\hline healthy & $34 \%$ & $\begin{array}{l}\text { aspects of } \\
\text { animal } \\
\text { husbandry }\end{array}$ & $24 \%$ & $\begin{array}{l}\text { without animal } \\
\text { ingredients }\end{array}$ & $31 \%$ & healthy & $23 \%$ & healthy & $25 \%$ \\
\hline $\begin{array}{l}\text { environmentally } \\
\text { friendly }\end{array}$ & $25 \%$ & $\begin{array}{l}\text { environmentally } \\
\text { friendly }\end{array}$ & $22 \%$ & healthy & $26 \%$ & vegan products & $17 \%$ & $\begin{array}{l}\text { other negative } \\
\text { associations }\end{array}$ & $21 \%$ \\
\hline $\begin{array}{l}\text { other positive } \\
\text { associations }\end{array}$ & $22 \%$ & $\begin{array}{l}\text { without animal } \\
\text { ingredients }\end{array}$ & $20 \%$ & $\begin{array}{l}\text { aspects of } \\
\text { animal } \\
\text { husbandry }\end{array}$ & $18 \%$ & little or no taste & $13 \%$ & unhealthy & $15 \%$ \\
\hline good taste & $18 \%$ & vegan products & $15 \%$ & vegan products & $16 \%$ & $\begin{array}{l}\text { other negative } \\
\text { associations }\end{array}$ & $12 \%$ & vegan products & $14 \%$ \\
\hline $\begin{array}{l}\text { without animal } \\
\text { ingredients }\end{array}$ & $13 \%$ & organic food & $14 \%$ & $\begin{array}{l}\text { other negative } \\
\text { associations }\end{array}$ & $16 \%$ & artificial & $12 \%$ & expensive & $13 \%$ \\
\hline $\begin{array}{c}\text { social } \\
\text { responsibility }\end{array}$ & $12 \%$ & artificial & $11 \%$ & $\begin{array}{l}\text { environmentally } \\
\text { friendly }\end{array}$ & $15 \%$ & unhealthy & $12 \%$ & organic food & $13 \%$ \\
\hline vegan products & $11 \%$ & good taste & $11 \%$ & artificial & $11 \%$ & expensive & $10 \%$ & fashion & $11 \%$ \\
\hline organic food & $9 \%$ & fashion & $11 \%$ & fashion & $10 \%$ & fashion & $8 \%$ & natural & $8 \%$ \\
\hline ethic & $9 \%$ & $\begin{array}{l}\text { other positive } \\
\text { associations }\end{array}$ & $10 \%$ & little or no taste & $9 \%$ & $\begin{array}{l}\text { environmentally } \\
\text { friendly }\end{array}$ & $8 \%$ & artificial & $6 \%$ \\
\hline expensive & $7 \%$ & expensive & $10 \%$ & $\begin{array}{l}\text { other positive } \\
\text { associations }\end{array}$ & $8 \%$ & $\begin{array}{l}\text { aspects of } \\
\text { animal } \\
\text { husbandry }\end{array}$ & $6 \%$ & little or no taste & $6 \%$ \\
\hline natural & $6 \%$ & ethics & $7 \%$ & good taste & $8 \%$ & $\begin{array}{l}\text { other positive } \\
\text { associations }\end{array}$ & $5 \%$ & $\begin{array}{l}\text { environmentally } \\
\text { friendly }\end{array}$ & $6 \%$ \\
\hline unhealthy & $6 \%$ & & & organic food & $7 \%$ & organic food & $5 \%$ & & \\
\hline & & & & $\begin{array}{l}\text { unhealthy } \\
\text { expensive }\end{array}$ & $\begin{array}{l}7 \% \\
6 \%\end{array}$ & & & & \\
\hline
\end{tabular}

The table shows mentions that were expressed by at least $5 \%$ of the respondents. Multiple answers possible. Associations that belong together in terms of subject matter are highlighted in the same colour.

One out of four vegans, $22 \%$ of the vegetarians and $15 \%$ of the former vegetarians associated vegan food with environmental friendliness or sustainability. Omnivores $(6 \%)$ and flexitarians ( $8 \%)$ mentioned these associations far less frequently. That vegan products are "organic food" was mainly mentioned by vegetarians (14\%) and omnivores (13\%). Several participants associated vegan food with the attribute "expensive", irrespective of their different diets ( $6 \%$ of former vegetarians to $13 \%$ of omnivores). Some of the respondents saw vegan food as a passing fashion or trend, although this appraisal was hardly ever stated by vegans themselves.

Of the vegans, $18 \%$ associated vegan food with having a good taste. As expected, vegans mentioned this association more often than any other group ( $2 \%$ of flexitarians to $11 \%$ of vegetarians). Indeed, no vegans criticized the taste of vegan food, while such criticisms were stated by participants in all other groups (3\% of vegetarians to $13 \%$ of flexitarians). Among those who ate meat at least occasionally (former vegetarians, flexitarians, and omnivores), the taste of vegan food was criticized more often than it was praised.

While vegan food was seen as "natural" by some participants, primarily by vegans $(6 \%)$ and omnivores $(8 \%)$, other respondents associated such food with being "artificial" ( $3 \%$ of vegans to $12 \%$ of flexitarians). Included in this category were not only responses that directly associated vegan products with being "artificial" but also those that described vegan food as "industrially processed" or that mentioned keywords such as "additives" or "chemicals". 


\subsection{Consumers' Attitudes towards Vegan Food}

The answers to the open-ended question were confirmed by querying the participants' attitudes towards vegan food using a semantic differential.

No significant differences were detected in the responses of the participants from different dietary groups in their evaluation of the origins of vegan food between the poles "imported" and "domestic" (Welch's $F(4,223.05)=1.288, p=0.300$ ). Nor was any clear tendency discernible, with all average values of the groups being in the centre (Figure 1).

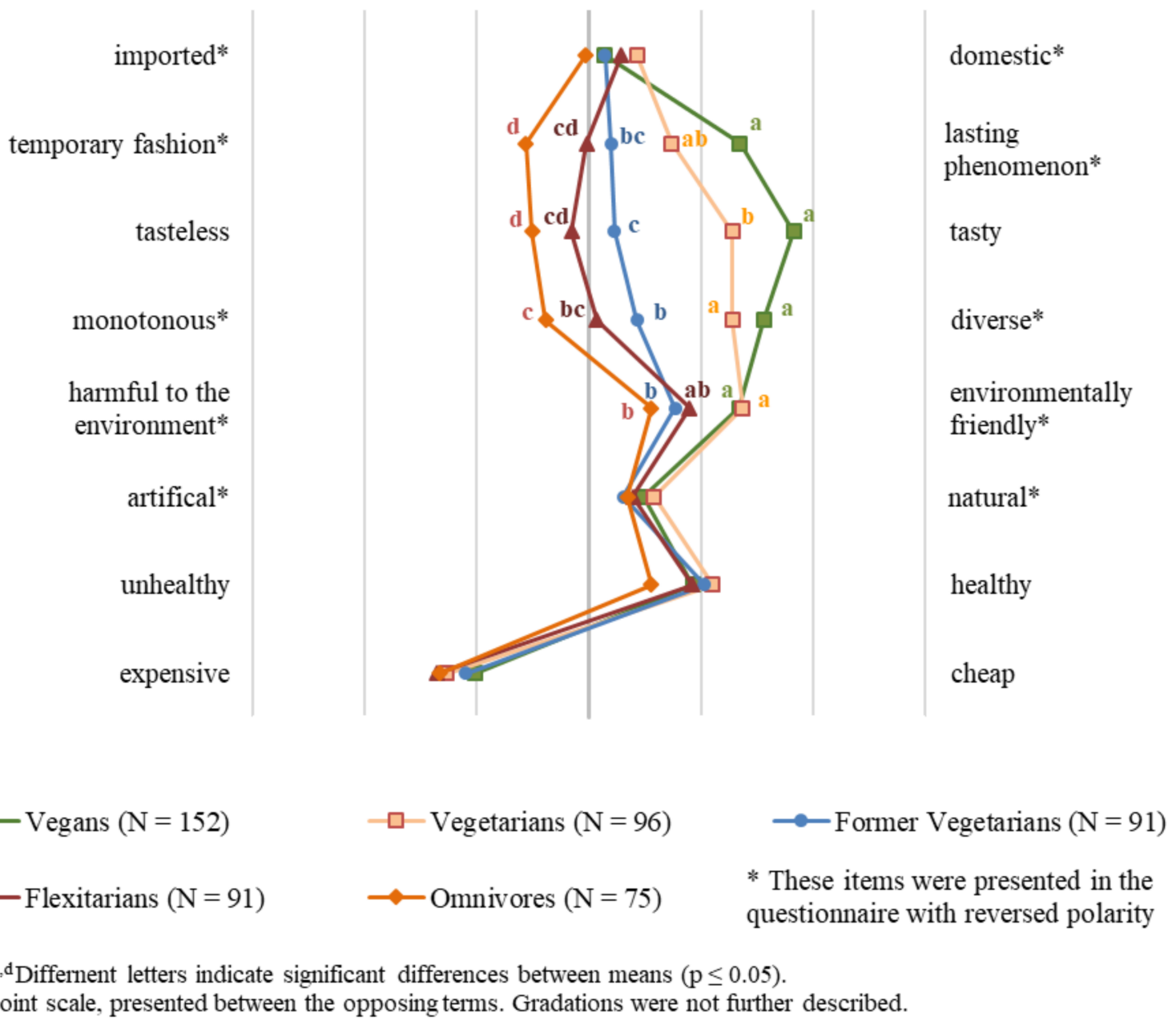

Figure 1. Perceptions of vegan food among people following different diets.

Vegan food was considered to be a lasting phenomenon rather than a passing trend by vegans more often than by those participants who ate meat from time to time, i.e., former vegetarians $($ mean $=4.20)$, flexitarians $($ mean $=3.98)$, and omnivores $($ mean $=3.44)$, $F(4,498)=19.586, p<0.001)$.

Regarding the participants' evaluation of the taste of vegan food, the vegan group differed significantly from those following other diets in positively appraising the taste of such food (Welch's $F(4,219.79)=51.406, p<0.001)$. Vegetarians $($ mean $=5.28)$ were more critical than vegans (mean $=5.83$ ) of the taste of vegan food, although they rated it significantly more positively than those participants who ate meat from time to time (former vegetarians $($ mean $=4.23)$, flexitarians $($ mean $=3.84)$, and omnivores $($ mean $=3.49)$ ). The most negative appraisals of the taste of vegan food were given by the omnivores, whose ratings were not only significantly more negative than those of vegans and vegetarians but also those of former vegetarians. 
The participants' evaluations of the "diversity" of vegan food were similar to their evaluations of taste and differed statistically significant between the different diets $(F(4,498)=29.085, p<0.001)$. Only vegans assessed the diversity of vegan products as slightly worse than previously the taste. Thus, no significant difference could be detected between vegans (mean $=5.56)$ and vegetarians $($ mean $=5.28)$ regarding their evaluation of the diversity of vegan products.

Overall, the respondents tended to appraise vegan food as environmentally friendly, although there were significant differences in the appraisals of the various diet groups $($ Welch's $F(4,224.19)=5.406, p<0.001)$, with vegans $($ mean $=5.34)$ and vegetarians (mean $=5.38$ ) seeing vegan food as more environmentally friendly than omnivores and former vegetarians $($ mean $=4.77)$.

The participants' evaluations of whether vegan food is "artificial" or "natural" revealed no differences between the diet groups (Welch's $F(4,223.21)=0.397, p=0.811$ ) Across the groups, a slight tendency towards "natural" could be observed. Vegan food was rated as "healthy" $(F(4,498)=1.499, p=0.201)$ and was perceived as "expensive" $(F(4,498)=1.478, p=0.208)$ by all of the dietary groups.

A PCA was carried out with all eight items from the semantic differential. The item regarding price perception (expensive vs. cheap) was excluded, however, since the communality of the variable was less than 0.5. After the exclusion of this variable, the conditions for the PCA were tested again and were all fulfilled (Bartlett's test of sphericity $\left(\mathrm{X}^{2}(21)=1.166,10, p<0.001\right.$, overall MSA value 0.82 , lowest MSA value of a single variable 0.73 ). The parallel analysis showed that the extraction of two factors was the most appropriate solution. This result was further confirmed by other common criteria for determining the number of factors, such as the Kaiser-Guttmann criterion and the Scree test. Each variable loaded only to one of the two factors. Factor 1 implies the perception of vegan food as "original" food, which includes the perception of vegan food as natural, environmentally friendly, healthy, and local in origin. The second factor is named "enjoyment", which includes perceptions of vegan food as tasty, diverse and as a long-term phenomenon. In order to examine whether the participants with different diets perceived vegan food differently, the factor means were compared. The only significant differences detected among the responses of those following different diets related to the factor of "enjoyment" (Welch's $F(4,216.15)=59.906, p<0.001)$ (Table 4$)$.

Table 4. Factor means per diet.

\begin{tabular}{|c|c|c|c|c|c|c|c|}
\hline & \multicolumn{5}{|c|}{ Means 1} & \multirow{3}{*}{ F-Value/Welch-Value } & \multirow{3}{*}{$p$-Value } \\
\hline & Vegans & Vegetarians & $\begin{array}{c}\text { Former } \\
\text { Vegetarians }\end{array}$ & Flexitarians & Omnivores & & \\
\hline & $(\mathrm{N}=152)$ & $(N=96)$ & $(\mathrm{N}=91)$ & $(N=89)$ & $(N=75)$ & & \\
\hline Original A & -0.12 & 0.10 & 0.00 & 0.08 & -0.11 & 1.171 & 0.323 \\
\hline Enjoyment ${ }^{B}$ & $0.70^{\mathrm{a}}$ & $0.31^{b}$ & $-0.27^{c}$ & $-0.49^{\mathrm{c}, \mathrm{d}}$ & $-0.75^{\mathrm{d}}$ & 59.906 & $<0.001$ \\
\hline
\end{tabular}

${ }^{1}$ The mean over all diets is 0 (factors are z-scores). ${ }^{\mathrm{A}}$ Assumption of homogeneity of variances is met (Levene-test, $\left.p>0.05\right) .{ }^{\mathrm{B}}$ Assumption of homogeneity of variances is not met (Levene-test, $p \leq 0.05$ ); ANOVA based on Welch-Test, post hoc test: Games-Howell. ${ }^{\text {a-d }}$ Different letters indicate significant differences between means $(p \leq 0.05)$.

The factors were used to group consumers into different clusters based on their attitudes towards vegan food. Using the hierarchical cluster method "single linkage", five outliers were identified and excluded from further calculations. The optimum number of clusters was identified as three in accordance with consideration of the dendrogram of Ward's hierarchical clustering method as well as by comparing the within-sum-of-squares values and the silhouette score of various k-means cluster solutions. To verify the cluster quality, the silhouette widths of the resulting clusters were checked. As can be seen in Figure 2, Cluster 1 contains four cases, and Cluster 2 contains two cases with negative silhouette width. This means that six cases overall were probably allocated to the wrong 
cluster. The average silhouette width is 0.38 . According to Kaufman and Rousseeuw [79] (p. 88), an average silhouette width in the range of 0.26 to 0.50 indicates that there is substantial structure in the data.

$1.00-$

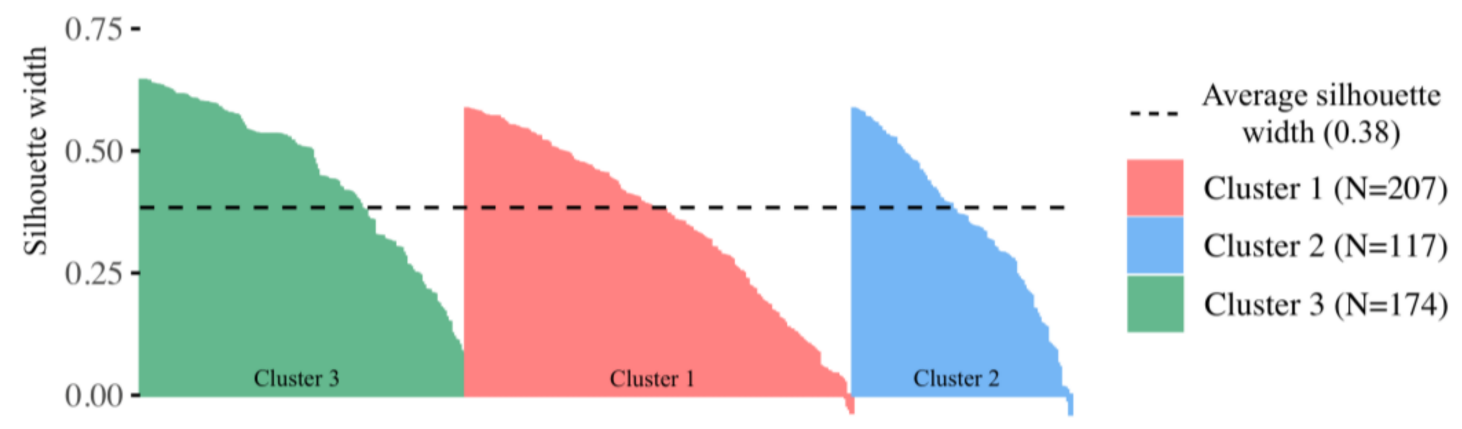

$$
\mathrm{N}=498
$$

Figure 2. The silhouette plot for the three clusters.

The created clusters are shown as a scatter plot in Figure 3. Consumers allocated to Cluster 1 did not perceive vegan food as "original", while those in Cluster 2 perceived vegan food as original but doubted the tastiness of such products. Cluster 3 included all those who perceived vegan food as both original and enjoyable.

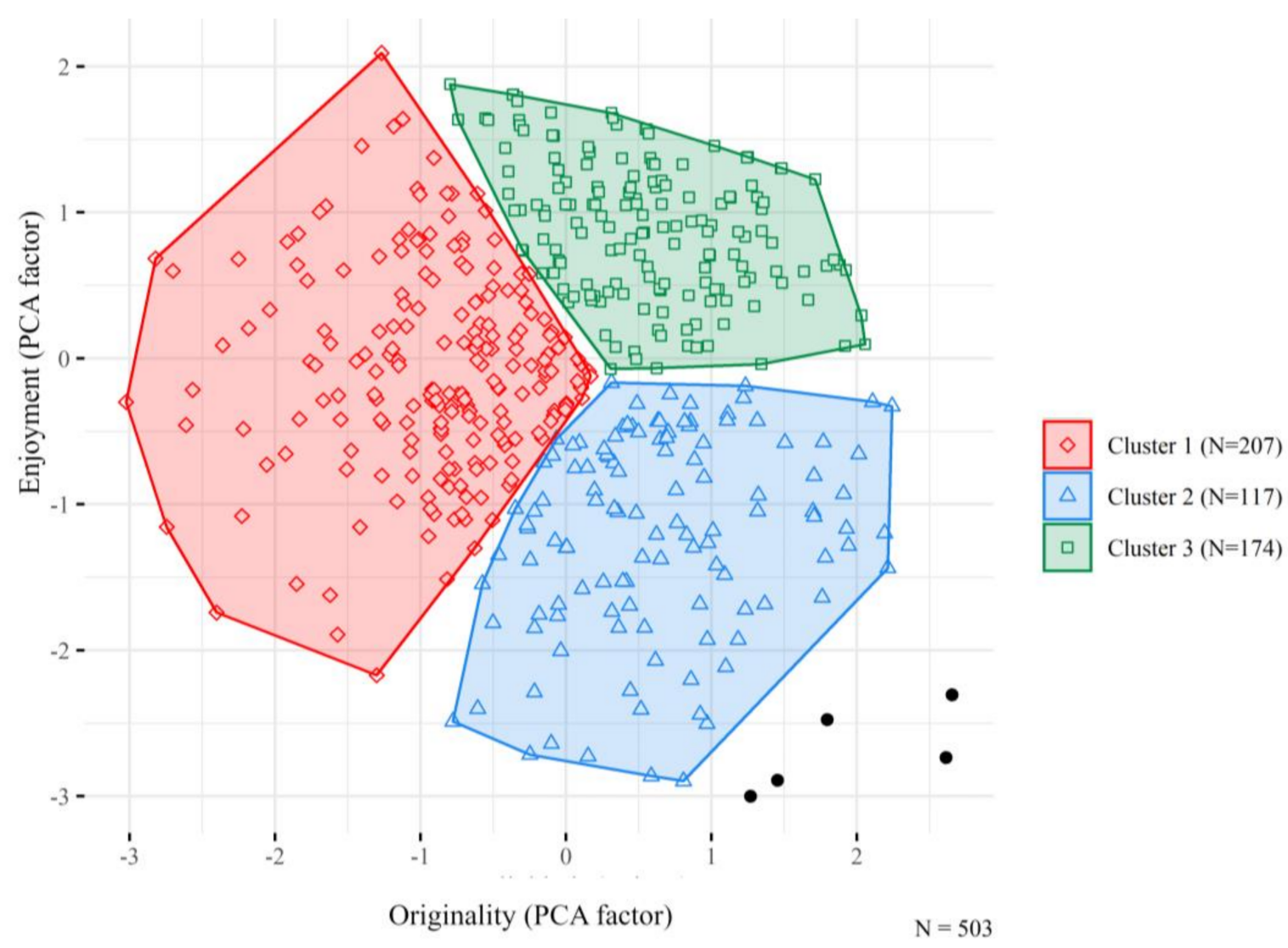

Figure 3. Scatter plot of the three clusters and the outliers (black points). 
For a simpler interpretation of the results, the initial variables that were included in the principal component analysis were used. Figure 4 shows how the three clusters differ in their perception of vegan food.

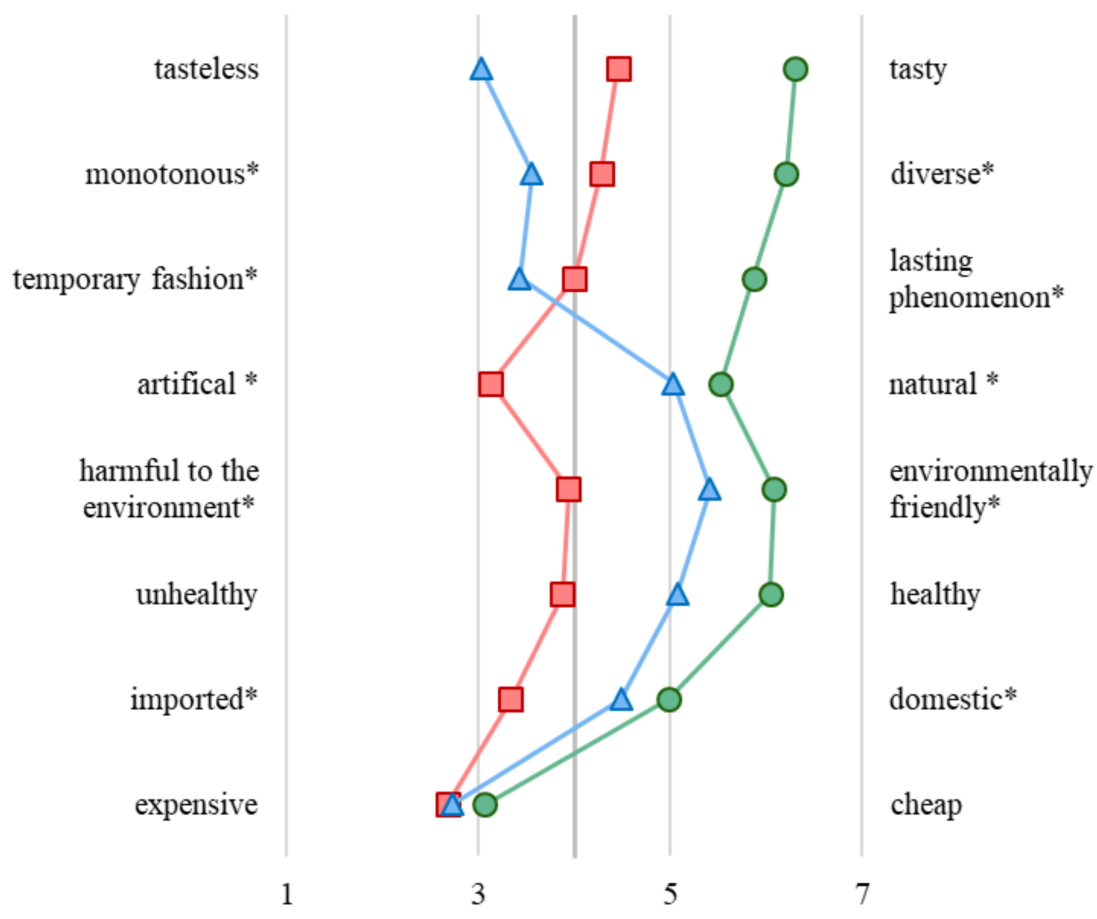

-Cluster 1: Originality-sceptics $(\mathrm{N}=207) \quad \triangle$ Cluster 2: Enjoyment-sceptics $(\mathrm{N}=117)$

Cluster 3: Vegan fans $(\mathrm{N}=174)$

* These items were presented in the questionnaire with reversed polarity

Figure 4. Perception of vegan food from the perspective of the clusters.

The three clusters were labelled "originality-sceptics" (Cluster 1), "enjoyment-sceptics" (Cluster 2), and "vegan fans" (Cluster 3). The "originality-sceptics" tended to perceive vegan food as artificial and imported and did not assess it either as healthy or environmentally friendly. The other two clusters both perceived the "originality" and "environmentally friendly" of vegan food positively, with the "vegan fans" rating these factors even more highly than the "enjoyment-sceptics".

A significant relationship was identified between diet group and cluster membership $\left(X^{2}(8)=114.757, p<0.001\right.$, Cramer's V = 0.339). According to Cohen [80] (p. 227), the effect size can be characterised as a medium effect. There were only a very small proportion of vegans (4\%) and vegetarians ( $9 \%$ ) among the "enjoyment-sceptics" cluster. Likewise, there were less former vegetarians (11\%), flexitarians (9\%), and omnivores (5\%) among the "vegan fans" cluster. Surprisingly, consumers from the "originality sceptics" cluster were found in almost equal proportions in all diet groups (Table 5). In terms of sociodemographic factors, the gender and age of the participants had no significant effect on the clusters to which they belonged.

Table 5. Segments of consumers: clustered groups and diet.

\begin{tabular}{ccccccc}
\hline & N & Vegans & Vegetarians & $\begin{array}{c}\text { Former } \\
\text { Vegetarians }\end{array}$ & Flexitarians & Omnivores \\
\hline Vegan fans & 174 & $50 \%$ & $25 \%$ & $11 \%$ & $9 \%$ & $5 \%$ \\
Enjoyment-sceptics & 117 & $4 \%$ & $9 \%$ & $24 \%$ & $33 \%$ & $30 \%$ \\
Originality-sceptics & 207 & $29 \%$ & $20 \%$ & $20 \%$ & $16 \%$ & $15 \%$ \\
\hline
\end{tabular}




\section{Discussion and Conclusions}

The socio-demographic characteristics show there were more women than men in the sample in all diet groups except for the omnivores. In addition, the average age of vegans and vegetarians was slightly lower in the sample than in the German population as a whole. However, these characteristics have already been observed in other studies. Women are often over-represented when recruiting survey participants in grocery shops (for example [46,81]), because grocery shopping in Germany is more often done by women [82] (pp. 116-117). Furthermore, women are more often vegetarians $[42,43,68,83]$. A lower age is also a typical characteristic of vegetarians [68].

Although the term "flexitarian" is not very precisely defined, the reported frequency of meat consumption by flexitarians in this study is in line with the results of previous studies on flexitarians $[19,61,69,84,85]$.

The three most frequently mentioned associations with vegan food stated by vegans and vegetarians, i.e., the issues of animal welfare, health, and environmental protection, are consistent with the most widely reported motives for choosing a vegan diet and the overall perception of veganism $[44-52,86]$. The conviction, that no distinction should be made between companion animals, farm animals, and wild animals often also leads to a vegetarian or even vegan diet [87].

For those participants who ate meat from time to time, only health was among their top three associations with vegan food products. In an earlier study on the reduction of meat consumption in Germany, personal reasons such as health benefits were also a frequently mentioned motive for a reduced meat consumption and altruistic reasons such as climate protection were generally of less importance [88]. While "healthy" and "natural" were stated by many participants as associations with vegan food, it is remarkable that some participants associated the terms "unhealthy" and "artificial" with these products. This confirms the results of previous studies about meat substitutes, which are perceived as healthy, but unhealthy on account of the many additives and the high degree of processing involved in the production of such substitutes $[27,28]$. While literature reviews have shown that giving up meat consumption is widely perceived as healthy, some people are also concerned that abstaining from meat could be unhealthy and lead to malnutrition $[25,89]$. In particular, many consumers are sceptical about the healthiness of a vegan diet, although a majority consider a vegan diet to be healthy [38].

The significant differences regarding the assessment of the environmental friendliness of vegan food between persons with different diets are consistent with the findings of previous studies: vegetarians are more environmentally concerned than flexitarians and meat eaters [62] and more often believe that meat production is bad for the environment $[17,20,61]$. However, it should also be considered that many consumers are not aware of the negative environmental impacts of meat consumption and underestimate them $[90,91]$. Consumers therefore wrongly perceive environmental protection through a reduction in meat consumption as less effective than other behavioural or consumption changes [92-95].

Participants who ate meat from time to time were significantly more concerned about and critical of the taste of vegan food than vegetarians and vegans. Such variations in perceptions of the taste of vegan products have been found in previous studies [34,36,37]. Importantly, the cluster analysis performed for the present study revealed a segment of consumers who have positive attitudes to vegan food but also have doubts as to the taste and variety of such food. In order to reduce the reluctance of this target group, it is necessary to underpin progress in the development of tasty products with additional communication measures and promotion. The fact that people with a vegetarian selfidentity do not miss the taste of meat may be an explanation for the low proportions of vegans and vegetarians in this cluster [96].

The analysis further revealed a consumer segment with doubts about the naturalness and "originality" of vegan products. Such doubts were expressed by participants from all five diet groups. In a study by Lemken et al. [97], a similar consumer segment was 
identified for whom it is particularly important that meat substitutes are only minimally processed and in a study by Hwang et al. [98] that the perception of unnaturalness of plant-based meat serves as a barrier to purchase. To differentiate from other substitute products, therefore, organic vegan food should be minimally processed and contain no additives. Serving consumers' demand for less processed foods is also advantageous for environmental and health reasons, as a high proportion of highly processed foods could reduce the environmental value and health benefits of the vegan diet [99-101].

To expand the target group for vegan food, the needs of the "originality-sceptics" and "enjoyment-sceptics" clusters should be addressed. Depending on the product, the focus may be more on the "originality-sceptics" or on the "enjoyment-sceptics". However, special importance should be attached to the taste of vegan products since some of the "originality-sceptics" also questioned the tastiness of vegan products. Studies have shown that the perceived taste characteristics have a strong influence on the purchase probability of vegan products $[24,102]$. Vegan food was perceived as "expensive" by all the study respondents irrespective of their different diets, further confirming the findings of previous studies $[35,36,103]$.

When comparing the associations to vegan food found in this study with associations to organic food in general, a large overlap emerges. A study by Hilverda et al. [104] found that "animal welfare", "price", "health", "pesticide use", and "naturalness" are the most frequently mentioned associations with organic food. Everything except "pesticide use" was also mentioned in this study as an association with vegan food. For organic food consumers, the health benefits of organic food in general are a key purchase motive, as a meta-analysis by Rana and Paul [105] shows. Other aspects such as environmental friendliness and animal welfare, which are also associated with vegan food, are further important motives for organic food consumers to buy organic food [105]. This overlap in the perception of organic and vegan food underlines the relevance of organic food consumers as a target group for vegan food.

In Germany, both vegan food and organic food in general have gained increasing public attention in recent years alongside wider public discussions about the environmental impacts of food production. It can therefore be assumed that changes in organic food consumers' perceptions and attitudes towards vegan food are of high interest to food suppliers. Given that this study provides only a snapshot of a particular consumer group in Germany, it would be of interest to ascertain the extent to which similar perceptions, consumption patterns, underlying attitudes and buying motives for vegan food exist among consumers in other countries.

Author Contributions: D.K. and U.H. contributed to designing the research. D.K. analysed the data and drafted the manuscript. U.H. contributed to the final manuscript. Both authors have read and agreed to the published version of the manuscript.

Funding: This work was founded by the Federal Ministry of Food and Agriculture within the framework of the Federal Program on Organic Farming, grant number 2815OE124.

Institutional Review Board Statement: Participation in the survey was voluntary and the survey was anonymous. Therefore, ethical review and approval are not required for the study in accordance with the local legislation and institutional requirements.

Informed Consent Statement: Informed consent was obtained from all subjects involved in the study.

Data Availability Statement: The data presented in this study are available on request from the corresponding author.

Acknowledgments: We thank Matt Jones for proofreading and copyediting this paper.

Conflicts of Interest: The authors declare no conflict of interest. The funders had no role in the design of the study; in the collection, analyses, or interpretation of data; in the writing of the manuscript; or in the decision to publish the results. 


\section{References}

1. Chai, B.C.; van der Voort, J.R.; Grofelnik, K.; Eliasdottir, H.G.; Klöss, I.; Perez-Cueto, F.J.A. Which diet has the least environmental impact on our planet? A systematic review of vegan, vegetarian and omnivorous diets. Sustainability 2019, 11, 4110. [CrossRef]

2. Clark, M.A.; Domingo, N.G.G.; Colgan, K.; Thakrar, S.K.; Tilman, D.; Lynch, J.; Azevedo, I.L.; Hill, J.D. Global food system emissions could preclude achieving the $1.5^{\circ}$ and $2{ }^{\circ} \mathrm{C}$ climate change targets. Science 2020, 370, 705-708. [CrossRef] [PubMed]

3. Bruno, M.; Thomsen, M.; Pulselli, F.M.; Patrizi, N.; Marini, M.; Caro, D. The carbon footprint of Danish diets. Clim. Chang. 2019, 156, 489-507. [CrossRef]

4. Kolbe, K. Mitigating climate change through diet choice: Costs and CO2 emissions of different cookery book-based dietary options in Germany. Adv. Clim. Chang. Res. 2020, 11, 392-400. [CrossRef]

5. Ivanova, D.; Barrett, J.; Wiedenhofer, D.; Macura, B.; Callaghan, M.; Creutzig, F. Quantifying the potential for climate change mitigation of consumption options. Environ. Res. Lett. 2020, 15, 93001. [CrossRef]

6. Drew, J.; Cleghorn, C.; Macmillan, A.; Mizdrak, A. healthy and climate-friendly eating patterns in the New Zealand context. Environ. Health Perspect. 2020, 128, 17007. [CrossRef]

7. Baroni, L.; Berati, M.; Candilera, M.; Tettamanti, M. Total environmental impact of three main dietary patterns in relation to the content of animal and plant food. Foods 2014, 3, 443-460. [CrossRef]

8. Boizot-Szantai, C.; Hamza, O.; Soler, L.-G. Organic consumption and diet choice: An analysis based on food purchase data in France. Appetite 2017, 117, 17-28. [CrossRef] [PubMed]

9. Christensen, T.; Denver, S.; Bøye Olsen, S. Consumer preferences for organic food and for the shares of meat and vegetables in an everyday meal. J. Int. Food Agribus. Mark. 2020, 32, 234-246. [CrossRef]

10. Denver, S.; Christensen, T. Organic food and health concerns: A dietary approach using observed data. NJAS—Wagening. J. Life Sci. 2015, 74, 9-15. [CrossRef]

11. Denver, S.; Nordström, J.; Christensen, T. Is an increase in organic consumption accompanied by a healthier diet? A comparison of changes in eating habits among Danish consumers. J. Food Prod. Mark. 2019, 25, 479-499. [CrossRef]

12. Petersen, S.B.; Rasmussen, M.A.; Strøm, M.; Halldorsson, T.I.; Olsen, S.F. Sociodemographic characteristics and food habits of organic consumers-A study from the Danish National Birth Cohort. Public Health Nutr. 2013, 16, 1810-1819. [CrossRef] [PubMed]

13. Kesse-Guyot, E.; Péneau, S.; Méjean, C.; Szabo de Edelenyi, F.; Galan, P.; Hercberg, S.; Lairon, D. Profiles of organic food consumers in a large sample of French adults: Results from the Nutrinet-Santé cohort study. PLoS ONE 2013, 8, e76998. [CrossRef] [PubMed]

14. Salvatori, G.; Forleo, M.B.; Martino, F.; Di Iuorio, E.; Piccinelli, R.; Di Cesare, C. The dietary adequacy of organic vs conventional food consumers. Prog. Nutr. 2021, 23, e2021067. [CrossRef]

15. German Federal Office for Agriculture and Food. Öko-Barometer 2020; German Federal Office for Agriculture and Food: Bonn, Germany, 2021; Available online: https: / / www.bmel.de/Oeko-Barometer-2020 (accessed on 26 July 2021).

16. Barr, S.I.; Chapman, G.E. Perceptions and practices of self-defined current vegetarian, former vegetarian, and nonvegetarian women. J. Am. Diet. Assoc. 2002, 102, 354-360. [CrossRef]

17. De Backer, C.J.S.; Hudders, L. From meatless Mondays to meatless Sundays: Motivations for meat reduction among vegetarians and semi-vegetarians who mildly or significantly reduce their meat intake. Ecol. Food Nutr. 2014, 53, 639-657. [CrossRef] [PubMed]

18. Forestell, C.A.; Spaeth, A.M.; Kane, S.A. To eat or not to eat red meat. A closer look at the relationship between restrained eating and vegetarianism in college females. Appetite 2012, 58, 319-325. [CrossRef]

19. Malek, L.; Umberger, W.J. Distinguishing meat reducers from unrestricted omnivores, vegetarians and vegans: A comprehensive comparison of Australian consumers. Food Qual. Prefer. 2021, 88, 104081. [CrossRef]

20. Mullee, A.; Vermeire, L.; Vanaelst, B.; Mullie, P.; Deriemaeker, P.; Leenaert, T.; de Henauw, S.; Dunne, A.; Gunter, M.J.; Clarys, P.; et al. Vegetarianism and meat consumption: A comparison of attitudes and beliefs between vegetarian, semi-vegetarian, and omnivorous subjects in Belgium. Appetite 2017, 114, 299-305. [CrossRef]

21. Ploll, U.; Stern, T. From diet to behaviour: Exploring environmental- and animal-conscious behaviour among Austrian vegetarians and vegans. Br. Food. J. 2020, 122, 3249-3265. [CrossRef]

22. He, J.; Evans, N.M.; Liu, H.; Shao, S. A review of research on plant-based meat alternatives: Driving forces, history, manufacturing, and consumer attitudes. Compr. Rev. Food Sci. Food Saf. 2020, 19, 2639-2656. [CrossRef] [PubMed]

23. Fehér, A.; Gazdecki, M.; Véha, M.; Szakály, M.; Szakály, Z. A comprehensive review of the benefits of and the barriers to the switch to a plant-based diet. Sustainability 2020, 12, 4136. [CrossRef]

24. Weinrich, R. Opportunities for the adoption of health-based sustainable dietary patterns: A review on consumer research of meat substitutes. Sustainability 2019, 11, 4028. [CrossRef]

25. Corrin, T.; Papadopoulos, A. Understanding the attitudes and perceptions of vegetarian and plant-based diets to shape future health promotion programs. Appetite 2017, 109, 40-47. [CrossRef]

26. Graça, J.; Truninger, M.; Junqueira, L.; Schmidt, L. Consumption orientations may support (or hinder) transitions to more plant-based diets. Appetite 2019, 140, 19-26. [CrossRef]

27. Elzerman, J.E.; Van Boekel, M.A.; Luning, P.A. Exploring meat substitutes: Consumer experiences and contextual factors. Br. Food. J. 2013, 115, 700-710. [CrossRef] 
28. Weinrich, R. Cross-cultural comparison between German, French and Dutch consumer preferences for meat substitutes. Sustainability 2018, 10, 1819. [CrossRef]

29. Haas, R.; Schnepps, A.; Pichler, A.; Meixner, O. Cow milk versus plant-based milk substitutes: A comparison of product image and motivational structure of consumption. Sustainability 2019, 11, 5046. [CrossRef]

30. Miguel, I.; Coelho, A.; Bairrada, C.M. Modelling attitude towards consumption of vegan products. Sustainability 2021, 13, 9. [CrossRef]

31. Raggiotto, F.; Mason, M.C.; Moretti, A. Religiosity, materialism, consumer environmental predisposition. Some insights on vegan purchasing intentions in Italy. Int. J. Consum. Stud. 2018, 42, 613-626. [CrossRef]

32. Shen, Y.-C.; Chen, H.-S. Exploring consumers' purchase intention of an innovation of the agri-food industry: A case of artificial meat. Foods 2020, 9, 745. [CrossRef]

33. Estell, M.; Hughes, J.; Grafenauer, S. Plant protein and plant-based meat alternatives: Consumer and nutrition professional attitudes and perceptions. Sustainability 2021, 13, 1478. [CrossRef]

34. Reipurth, M.F.; Hørby, L.; Gregersen, C.G.; Bonke, A.; Perez Cueto, F.J. Barriers and facilitators towards adopting a more plant-based diet in a sample of Danish consumers. Food Qual. Prefer. 2019, 73, 288-292. [CrossRef]

35. Michel, F.; Hartmann, C.; Siegrist, M. Consumers' associations, perceptions and acceptance of meat and plant-based meat alternatives. Food Qual. Prefer. 2021, 87, 104063. [CrossRef]

36. Van Loo, E.J.; Hoefkens, C.; Verbeke, W. Healthy, sustainable and plant-based eating: Perceived (mis)match and involvementbased consumer segments as targets for future policy. Food Policy 2017, 69, 46-57. [CrossRef]

37. Clark, L.F.; Bogdan, A.-M. The role of plant-based foods in canadian diets: A survey examining food choices, motivations and dietary identity. J. Food Prod. Mark. 2019, 25, 355-377. [CrossRef]

38. Bryant, C.J. We can't keep meating like this: Attitudes towards vegetarian and vegan diets in the United Kingdom. Sustainability 2019, 11, 6844. [CrossRef]

39. International Vegetarian Union. Definitions. Available online: https://ivu.org/definitions.html (accessed on 26 August 2021).

40. Oxford English Dictionary Online. Flexitarian, noun and adjective.; Oxford University Press: Oxford, UK, 2019; Available online: www.oed.com/view/Entry/407583 (accessed on 26 August 2021).

41. Derbyshire, E.J. Flexitarian diets and health: A review of the evidence-based literature. Front. Nutr. 2017, 3, 55. [CrossRef]

42. Ruby, M.B. Vegetarianism. A blossoming field of study. Appetite 2012, 58, 141-150. [CrossRef]

43. Rosenfeld, D.L. The psychology of vegetarianism: Recent advances and future directions. Appetite 2018, 131, 125-138. [CrossRef] [PubMed]

44. Dyett, P.A.; Sabaté, J.; Haddad, E.; Rajaram, S.; Shavlik, D. Vegan lifestyle behaviors. An exploration of congruence with health-related beliefs and assessed health indices. Appetite 2013, 67, 119-124. [CrossRef]

45. Fiestas-Flores, J.; Pyhälä, A. Dietary motivations and challenges among animal rights advocates in Spain. Soc. Anim. 2018, 26, 402-425. [CrossRef]

46. Janssen, M.; Busch, C.; Rödiger, M.; Hamm, U. Motives of consumers following a vegan diet and their attitudes towards animal agriculture. Appetite 2016, 105, 643-651. [CrossRef] [PubMed]

47. Kerschke-Risch, P. Vegan diet: Motives, approach and duration: Initial results of a quantitative sociologicalstudy. Ernahr. Umsch. 2015, 62, 98-103. [CrossRef]

48. Kessler, C.S.; Holler, S.; Joy, S.; Dhruva, A.; Michalsen, A.; Dobos, G.; Cramer, H. Personality profiles, values and empathy: Differences between lacto-ovo-vegetarians and vegans. Forsch. Komplementmed. 2016, 23, 95-102. [CrossRef]

49. Radnitz, C.; Beezhold, B.; DiMatteo, J. Investigation of lifestyle choices of individuals following a vegan diet for health and ethical reasons. Appetite 2015, 90, 31-36. [CrossRef] [PubMed]

50. Rothgerber, H. A meaty matter. Pet diet and the vegetarian's dilemma. Appetite 2013, 68, 76-82. [CrossRef]

51. Timko, C.A.; Hormes, J.M.; Chubski, J. Will the real vegetarian please stand up? An investigation of dietary restraint and eating disorder symptoms in vegetarians versus non-vegetarians. Appetite 2012, 58, 982-990. [CrossRef] [PubMed]

52. Waldmann, A.; Koschizke, J.W.; Leitzmann, C.; Hahn, A. Dietary intakes and lifestyle factors of a vegan population in Germany: Results from the German Vegan Study. Eur. J. Clin. Nutr. 2003, 57, 947-955. [CrossRef]

53. Fresán, U.; Errendal, S.; Craig, W.J. Influence of the socio-cultural environment and external factors in following plant-based diets. Sustainability 2020, 12, 9093. [CrossRef]

54. Simons, J.; Vierboom, C.; Klink-Lehmann, J.; Härlen, I.; Hartmann, M. Vegetarianism/veganism: A way to feel good. Sustainability 2021, 13, 3618. [CrossRef]

55. Haverstock, K.; Forgays, D.K. To eat or not to eat. A comparison of current and former animal product limiters. Appetite 2012, 58, 1030-1036. [CrossRef] [PubMed]

56. Menzies, K.; Sheeshka, J. The process of exiting vegetarianism: An exploratory study. Can. J. Diet. Pract. Res. 2012, 73, 163-168. [CrossRef] [PubMed]

57. Hodson, G.; Earle, M. Conservatism predicts lapses from vegetarian/vegan diets to meat consumption (through lower social justice concerns and social support). Appetite 2018, 120, 75-81. [CrossRef] [PubMed]

58. De Backer, C.J.S.; Hudders, L. Meat morals: Relationship between meat consumption consumer attitudes towards human and animal welfare and moral behavior. Meat Sci. 2015, 99, 68-74. [CrossRef] 
59. Rosenfeld, D.L.; Rothgerber, H.; Tomiyama, A.J. From mostly vegetarian to fully vegetarian: Meat avoidance and the expression of social identity. Food Qual. Prefer. 2020, 85, 103963. [CrossRef]

60. Izmirli, S.; Phillips, C.J. The relationship between student consumption of animal products and attitudes to animals in Europe and Asia. Br. Food. J. 2011, 113, 436-450. [CrossRef]

61. Hagmann, D.; Siegrist, M.; Hartmann, C. Meat avoidance: Motives, alternative proteins and diet quality in a sample of Swiss consumers. Public Health Nutr. 2019, 22, 2448-2459. [CrossRef]

62. Janda, S.; Trocchia, P.J. Vegetarianism: Toward a greater understanding. Psychol. Mark. 2001, 18, 1205-1240. [CrossRef]

63. Mylan, J. Sustainable consumption in everyday life: A qualitative study of UK consumer experiences of meat reduction. Sustainability 2018, 10, 2307. [CrossRef]

64. Forestell, C.A. Flexitarian diet and weight control: Healthy or risky eating behavior? Front. Nutr. 2018, 5, 59. [CrossRef]

65. German Federal Ministry of Food and Agriculture. Deutschland, Wie es Isst: Der BMEL-Ernährungsreport 2020; German Federal Ministry of Food and Agriculture: Berlin, Germany, 2020; Available online: https:/ /www.bmel.de/SharedDocs/Downloads / DE/Broschueren/ernaehrungsreport-2020.pdf?_blob=publicationFile\&v=19 (accessed on 26 July 2021).

66. IfD Allensbach. Allensbacher Marktanalyse Werbeträgeranalyse 2019; Institut für Demoskopie: Allensbach, Germany, 2019; Available online: https://www.ifd-allensbach.de/fileadmin/AWA/AWA2019/Codebuchausschnitte/AWA2019_Codebuch_Essen_und_ Trinken.pdf (accessed on 26 July 2021).

67. IfD Allensbach. Allensbacher Marktanalyse Werbeträgeranalyse 2020; Institut für Demoskopie: Allensbach, Germany, 2020; Available online: https://www.ifd-allensbach.de/fileadmin/AWA/AWA2020/Codebuchausschnitte/AWA2020_Codebuch_Essen_und_ Trinken.pdf (accessed on 26 July 2021).

68. Pfeiler, T.M.; Egloff, B. Examining the "Veggie" personality: Results from a representative German sample. Appetite 2018, 120, 246-255. [CrossRef] [PubMed]

69. Cordts, A.; Spiller, A.; Nitzko, S.; Grethe, H.; Duman, N. Study image problems affect consumption carefree meat-eaters, flexitarian and vegetarians (for life). Fleischwirtschaft 2013, 93, 59-63.

70. Kuckartz, U. Qualitative Text Analysis: A Guide to Methods, Practice \& Using Software; Sage: London, UK, 2014 ; ISBN 9781446267745.

71. Field, A.; Miles, J.; Field, Z. Discovering Statistics Using R; Sage: Los Angeles, CA, USA, 2012; ISBN 9781446289136.

72. Hair, J.F. Multivariate Data Analysis: A Global Perspective, 7th ed.; Pearson: Upper Saddle River, NJ, USA, 2010; ISBN 9780135153093.

73. Horn, J.L. A rationale and test for the number of factors in factor analysis. Psychometrika 1965, 30, 179-185. [CrossRef]

74. Dolnicar, S.; Grün, B.; Leisch, F. Market Segmentation Analysis: Understanding It, Doing It, and Making It Useful; Springer Open: Singapore, 2018; ISBN 9789811088179.

75. Malik, A.; Tuckfield, B. Applied Unsupervised Learning with R: Uncover Hidden Relationships and Patterns with K-Means Clustering, Hierarchical Clustering, and PCA; Packt Publishing: Birmingham, UK, 2019; ISBN 1789951461.

76. Everitt, B.; Landau, S.; Leese, M.; Stahl, D. Cluster Analysis, 5th ed.; Wiley: Chichester, UK, 2011; ISBN 9780470977811.

77. Federal Statistical Office Germany. Genesis-Online Database: Table Code 12411-0003 “Bevölkerung, Deutschland, Stichtag, Geschlecht". Available online: https:/ / www-genesis.destatis.de/genesis/online (accessed on 26 July 2021).

78. Federal Statistical Office Germany. Bevölkerung und Erwerbstätigkeit 2016: Bevölkerungsfortschreibung auf Grundlage des Zensus. 2011. Available online: https:/ / www.statistischebibliothek.de/mir/receive/DEHeft_mods_00096721 (accessed on 26 July 2021).

79. Kaufman, L.; Rousseeuw, P.J. Finding Groups in Data: An Introduction to Cluster Analysis; Wiley: New York, NY, USA, 1990; ISBN 0471878766.

80. Cohen, J. Statistical Power Analysis for the Behavioral Sciences, 2nd ed.; Erlbaum: Hillsdale, MI, USA, 1988 ; ISBN 0805802835.

81. Risius, A.; Hamm, U. Exploring influences of different communication approaches on consumer target groups for ethically produced beef. J. Agric. Environ. Ethics 2018, 31, 325-340. [CrossRef]

82. Max-Rubner-Institut. Nationale Verzehrsstudie II: Ergebnisbericht, Teil I.; Max-Rubner-Institut: Karlsruhe, Germany, 2008; Available online: https:/ /nbn-resolving.org/urn:nbn:de:gbv:ka51-2008080507 (accessed on 26 July 2021).

83. Modlinska, K.; Adamczyk, D.; Maison, D.; Pisula, W. Gender differences in attitudes to vegans/vegetarians and their food preferences, and their implications for promoting sustainable dietary patterns-a systematic review. Sustainability 2020, $12,6292$. [CrossRef]

84. Ploll, U.; Petritz, H.; Stern, T. A social innovation perspective on dietary transitions: Diffusion of vegetarianism and veganism in Austria. Environ. Innov. Soc. Transit. 2020, 36, 164-176. [CrossRef]

85. Rosenfeld, D.L.; Rothgerber, H.; Tomiyama, A.J. Mostly vegetarian, but flexible about it: Investigating how meat-reducers express social identity around their diets. Soc. Psychol. Pers. Sci. 2020, 11, 406-415. [CrossRef]

86. North, M.; Kothe, E.; Klas, A.; Ling, M. How to define "Vegan": An exploratory study of definition preferences among omnivores vegetarians and vegans. Food Qual. Prefer. 2021, 93, 104246. [CrossRef]

87. Hölker, S.; Meyer-Höfer, M.V.; Spiller, A. Animal ethics and eating animals: Consumer segmentation based on domain-specific values. Sustainability 2019, 11, 3907. [CrossRef]

88. Mohr, M.; Schlich, M. Socio-demographic basic factors of German customers as predictors for sustainable consumerism regarding foodstuffs and meat products. Int. J. Consum. Stud. 2016, 40, 158-167. [CrossRef]

89. Sanchez-Sabate, R.; Badilla-Briones, Y.; Sabaté, J. Understanding attitudes towards reducing meat consumption for environmental reasons. A qualitative synthesis review. Sustainability 2019, 11, 6295. [CrossRef] 
90. Sanchez-Sabate, R.; Sabaté, J. Consumer attitudes towards environmental concerns of meat consumption: A systematic review. Int. J. Environ. Res. Public Health 2019, 16, 1220. [CrossRef] [PubMed]

91. Hartmann, C.; Siegrist, M. Consumer perception and behaviour regarding sustainable protein consumption: A systematic review. Trends Food Sci. Technol. 2017, 61, 11-25. [CrossRef]

92. Stoll-Kleemann, S.; Schmidt, U.J. Reducing meat consumption in developed and transition countries to counter climate change and biodiversity loss: A review of influence factors. Reg. Environ. Chang. 2017, 17, 1261-1277. [CrossRef]

93. Vanhonacker, F.; Van Loo, E.J.; Gellynck, X.; Verbeke, W. Flemish consumer attitudes towards more sustainable food choices. Appetite 2013, 62, 7-16. [CrossRef]

94. De Boer, J.; de Witt, A.; Aiking, H. Help the climate, change your diet: A cross-sectional study on how to involve consumers in a transition to a low-carbon society. Appetite 2016, 98, 19-27. [CrossRef] [PubMed]

95. Austgulen, M.; Skuland, S.; Schjøll, A.; Alfnes, F. Consumer readiness to reduce meat consumption for the purpose of environmental sustainability: Insights from Norway. Sustainability 2018, 10, 3058. [CrossRef]

96. Schenk, P.; Rössel, J.; Scholz, M. Motivations and constraints of meat avoidance. Sustainability 2018, 10, 3858. [CrossRef]

97. Lemken, D.; Spiller, A.; Schulze-Ehlers, B. More room for legume-Consumer acceptance of meat substitution with classic, processed and meat-resembling legume products. Appetite 2019, 143, 104412. [CrossRef]

98. Hwang, J.; You, J.; Moon, J.; Jeong, J. Factors affecting consumers' alternative meats buying intentions: Plant-based meat alternative and cultured meat. Sustainability 2020,12, 5662. [CrossRef]

99. Rosi, A.; Mena, P.; Pellegrini, N.; Turroni, S.; Neviani, E.; Ferrocino, I.; Di Cagno, R.; Ruini, L.; Ciati, R.; Angelino, D.; et al. Environmental impact of omnivorous, ovo-lacto-vegetarian, and vegan diet. Sci. Rep. 2017, 7, 6105. [CrossRef] [PubMed]

100. Alcorta, A.; Porta, A.; Tárrega, A.; Alvarez, M.D.; Vaquero, M.P. Foods for plant-based diets: Challenges and innovations. Foods 2021, 10, 293. [CrossRef] [PubMed]

101. Gehring, J.; Touvier, M.; Baudry, J.; Julia, C.; Buscail, C.; Srour, B.; Hercberg, S.; Péneau, S.; Kesse-Guyot, E.; Allès, B. Consumption of ultra-processed foods by pesco-vegetarians, vegetarians, and vegans: Associations with duration and age at diet initiation. $J$. Nutr. 2021, 151, 120-131. [CrossRef] [PubMed]

102. Pandey, S.; Ritz, C.; Perez-Cueto, F.J.A. An application of the theory of planned behaviour to predict intention to consume plant-based yogurt alternatives. Foods 2021, 10, 148. [CrossRef]

103. Coffino, J.A.; Heiss, S.; Hormes, J.M. Perception vs. realitiy: Is it more expensive to grocery shop on a vegan/vegetarian diet? Ann. Behav. Med. 2017, 51, 1081. [CrossRef]

104. Hilverda, F.; Jurgens, M.; Kuttschreuter, M. Word associations with "organic": What do consumers think of? Br. Food J. 2016, 118, 2931-2948. [CrossRef]

105. Rana, J.; Paul, J. Health motive and the purchase of organic food: A meta-analytic review. Int. J. Consum. Stud. 2020, 44, 162-171. [CrossRef] 